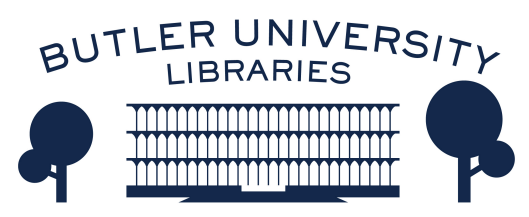

Journal of Hindu-Christian Studies

Volume 24

Article 1

November 2011

\title{
Table of Contents and Editorial Information
}

Follow this and additional works at: https://digitalcommons.butler.edu/jhcs

Part of the Religion Commons

\section{Recommended Citation}

(2011) "Table of Contents and Editorial Information," Journal of Hindu-Christian Studies: Vol. 24, Article 1. Available at: https://doi.org/10.7825/2164-6279.1478

The Journal of Hindu-Christian Studies is a publication of the Society for Hindu-Christian Studies. The digital version is made available by Digital Commons @ Butler University. For questions about the Journal or the Society, please contact cbauman@butler.edu. For more information about Digital Commons @ Butler University, please contact digitalscholarship@butler.edu. 


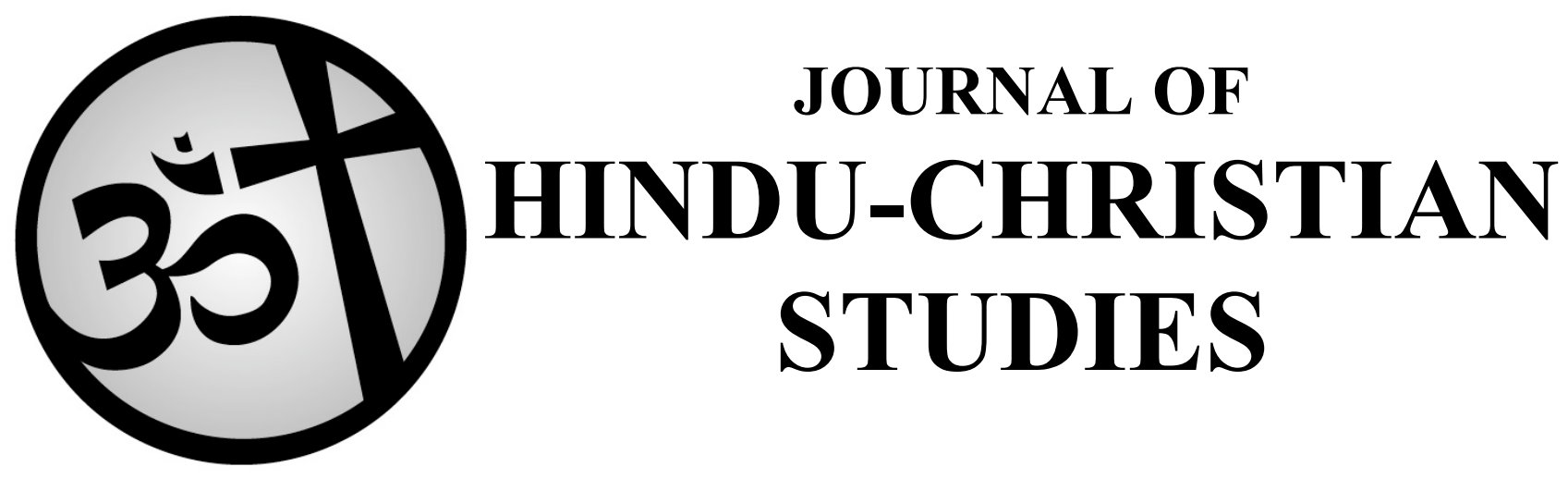

VOLUME 24, 2011

Theme Articles: Discussion of Michelle Voss Roberts, Dualities: A Theology of Difference

BRADLEY MALKOVSKY, Editor's Introduction 1

LANCE NELSON, Dualities and Women's Wisdom in Hinduism: Voss Roberts on Lalleśvarī of Kashmir. 3

LAUREL C. SCHNEIDER, Michelle Voss Roberts' Dualities..................................10

BRAD BANNON, Playing in the Flood of Love: A Response to Michelle Voss Roberts' Dualities: A Theology of Difference.

FRANCIS X. CLOONEY, S.J., A Response to Michelle Voss Roberts' Dualities .22 MICHELLE VOSS ROBERTS, Author Response.

Other Articles:

KLAUS K. KLOSTERMAIER, A Literary Hindu-Christian Dialogue a Century Ago: Still Active?

EDWARD T. ULRICH, Convergences and Divergences: The Lives of Swami Abhishiktananda and Raimundo Panikkar.

Viewpoint:

PRAVRAJIKA SARADESHAPRANA and TRACY SAYUKI TIEMEIER,

Teaching Hinduism in Catholic High Schools. .46

Reports and News: .51 


\section{EDITORS}

\section{EDITOR:}

Bradley J. Malkovsky

232 Malloy Hall

University of Notre Dame

Notre Dame, IN 46556 USA

email: bmalkovs@nd.edu

\section{Co-EdiTOR:}

Michael Amaladoss, SJ

Institute of Dialogue with Cultures and Religions

Loyola College, Nungambakkam

Chennai - 600 034, INDIA

mamaladoss@hotmail.com

Production Assistant: Cheryl A. Reed

\section{EDITORIAL ADVISORY BOARD}

\author{
John Carman \\ Harvard Divinity School \\ Francis X. Clooney, S.J. \\ Harvard University \\ Harold Coward \\ University of Victoria \\ J. T. K. Daniel \\ Serampore College \\ Corinne Dempsey \\ Nazareth College \\ Gavin Flood \\ Oxford Centre for Hindus Studies \\ Eliza Kent \\ Colgate University \\ Klaus Klostermaier \\ University of Manitoba
}

\author{
Gerald Larson \\ University of California at Santa Barbara \\ Julius Lipner \\ University of Cambridge \\ Rachel McDermott \\ Barnard College \\ Anantanand Rambachan \\ St. Olaf College \\ Chakravarthi Ram-Prasad \\ Lancaster University \\ Noel Sheth, S.J. \\ Jnana-Deepa-Vidyapeeth \\ Richard Fox Young \\ Princeton Theological Seminary
}

\section{EDITORIAL POLICY}

The Journal of Hindu-Christian Studies is an annual scholarly journal published jointly at the University of Notre Dame and at the Institute of Philosophy and Culture, Madras, India. It is the official publication of the Society for Hindu-Christian Studies.

The aim of the Journal is to create a worldwide forum for the presentation of Hindu-Christian scholarly studies, book reviews, and news of past and upcoming events. Materials selected for publication will be balanced between historical research and contemporary practice and, where possible, will employ analytical and theoretical analysis set within the context of our shared contemporary experience. Contributions are invited and may be addressed to either the Editor. Articles of roughly 4000 words are preferred, though occasionally longer pieces will be published. Send manuscript in paper form as well as on diskette. A style sheet is available on request. The Journal adopts a policy of non-gender-specific language where applicable. All articles are subject to review before acceptance and may be edited in the course of publication.

\section{SUBSCRIPTION INFORMATION}

An annual subscription is included with membership in the Society for Hindu-Christian Studies. For membership rates see www.hcstudies.org/mem.html. Subscriptions to the journal (digital only/digital + print) are $\$ 25 / \$ 35$ for non-Indian institutions; free/ $\$ 20$ for Indian institutions; $\$ 10 / 20$ for individuals outside of India; and free/ $\$ 15$ for individuals in India. Single copies of back issues are $\$ 15$. No other currencies can be accepted. To subscribe, visit www.hcstudies.org. The Journal is indexed in the ATLA Religion Database, published by the American Theological Library Association.

\section{JOURNAL OF HINDU-CHRISTIAN STUDIES}

